\title{
Zastosowanie tradycyjnych i nowoczesnych metod w doskonaleniu materiałów hodowlanych buraka cukrowego (Beta vulgaris L.)
}

\author{
Use of traditional and modern methods in the improvement of breeding material \\ of sugar beet (Beta vulgaris L.)
}

\section{Sandra Cichorz ${ }^{\bowtie}$, Małgorzata Malicka, Kamilla Kużdowicz, Barbara Skibowska, Maria Gośka}

Pracownia Cytogenetyki i Metodyki Hodowli, Zakład Genetyki i Hodowli Roślin Korzeniowych, Instytut Hodowli i Aklimatyzacji Roślin — Państwowy Instytut Badawczy, Oddział w Bydgoszczy

$\bowtie$ e-mail: sandra.cichorz@interia.pl; s.cichorz@ihar.bydgoszcz.pl

\begin{abstract}
W niniejszym doniesieniu zostały zaprezentowane najważniejsze osiągnięcia w zakresie zagadnień badawczych realizowanych w Pracowni Cytogenetyki i Metodyki Hodowli, Zakładu Genetyki i Hodowli Roślin Korzeniowych Oddziału IHAR-PIB w Bydgoszczy. Obejmują one: produkcję podwojonych haploidów, ochronę zasobów genowych, ocenę i selekcję genotypów odpornych na grzyb Cercospora beticola Sacc. oraz identyfikację genotypów w kierunku tolerancji na stres suszy w materiałach hodowlanych buraka cukrowego (Beta vulgaris L.).
\end{abstract}

Słowa kluczowe: gatunki dzikie, gynogeneza, kolekcje roślin, podwojone haploidy, susza

This communication presents the most important achievements in the field of research issues carried out in the Laboratory of Cytogenetics and Methodology of Breeding, Department of Genetics and Plant Breeding of the Branch of the IHAR-PIB in Bydgoszcz. They include: production of doubled haploids, protection of gene resources, evaluation and selection of fungal resistant genres of Cercospora beticola Sacc. and identification of genotypes towards tolerance to drought stress in sugar beet (Beta vulgaris L.) breeding material.

Key words: wild species, gynogenesis, plant collections, doubled haploids, drought

Burak cukrowy należy do roślin korzeniowych o szczególnym znaczeniu gospodarczym dla Polski. W strefie klimatu umiarkowanego stanowi najważniejszy surowiec do produkcji cukru. Zgodnie z danymi Eurostatu powierzchnia uprawy buraka na terenie naszego kraju w 2017 r. wyniosła ok. 223 tys. ha, co umiejscawia Polskę obok Francji, Niemiec i Turcji w czołówce uprawiających go państw Unii Europejskiej. Hodowla twórcza tego gatunku wymaga nieustannego postępu W zakresie wysokości i jakości plonowania, szczególnie w warunkach, gdy roślina poddana jest działaniu stresu abiotycznego i biotycznego. Jest to możliwe do uzyskania dzięki wykorzystaniu tradycyjnych metod hodowlanych wspartych nowoczesnymi osiągnięciami biotechnologii i biologii molekularnej.

Obecnie trudno jest wyobrazić sobie tworzenie materiałów wyjściowych do hodowli odmian buraka bez wykorzystania szerokiego spektrum metod in vitro. Techniki te mają istotne znaczenie, szczególnie w produkcji haploidów i podwojonych haploidów, efektywnym rozmnażaniu cennych genotypów oraz ochronie zasobów genowych o szerokim zakresie zmienności genetycznej. Opracowanie i wdrożenie do praktyki rolniczej metod mikrorozmnażania z merystemów wierzchołkowych oraz pachwinowych, a także otrzymywania haploidów i podwojonych haploidów $\mathrm{w}$ kulturach in vitro z niezapłodnionych zalążków jednonasiennych i wielonasiennych linii buraka cukrowego stało się możliwe dzięki pionierskim pracom wykonanym przez dr hab. Marię Gośka, prof. nadzw. IHAR - PIB w Bydgoszczy (Gośka, 1997). Opracowaną metodykę udostępniono Kutnowskiej Hodowli Buraka Cukrowego Sp. z o.o., Stacji Hodowli Roślin w Straszkowie, gdzie wartościowe linie homozygotyczne wykorzystywane są w hodowli odmian heterozyjnych oraz $\mathrm{w}$ hodowli odpornościowej. Stabilne i relatywnie proste metody produkcji podwojonych haploidów na dużą skalę pozwalają na znaczne przyspieszenie tempa i obniżenie kosztów hodowli odmian buraka cukrowego. Ponadto, coraz częściej szanse na zwiększenie konkurencyjności polskiej hodowli buraka upatruje się w diagnostyce molekularnej, pozwalającej na identyfikację odporności na poszczególne patogeny, dobór komponentów o największym dystansie genetycznym lub ocenę stabilności genetycznej linii hodowlanych. 
Powszechnie przyjęta na świecie metodyka hodowli jednonasiennych odmian mieszańcowych syntetyzowanych z wykorzystaniem linii męskosterylnych spowodowała szybkie wycofywanie $\mathrm{z}$ uprawy genotypów o dużym zakresie zmienności i cennych cechach użytkowych. $\mathrm{Z}$ czasem konieczne stało się zgromadzenie i zabezpieczenie przed wyginięciem zróżnicowanych populacji buraka cukrowego i pastewnego, a także gatunków dzikich, którym w niedalekiej przyszłości grozi wymarcie na skutek postępu cywilizacyjnego. Taką rolę pełni powstała w 1981 roku polska kolekcja buraka, której celem jest zachowanie cennych zasobów genowych buraka ex situ. Kolekcja polowa wieloletnich gatunków dzikich buraka sekcji Corollinae mieszcząca się na poletkach doświadczalnych Oddziału IHAR - PIB w Bydgoszczy powstała na bazie materiałów pochodzących z naturalnych stanowisk. Gatunki zgromadzone w tej kolekcji i ich mieszańce międzygatunkowe stanowią bardzo cenne źródło genów warunkujących odporność na suszę i wahania temperatury oraz na powszechne choroby grzybowe i wirusowe buraka. Obecnie w kolekcji przechowywane sa i rozmnażane in vitro dzikie gatunki, które naturalnie zasiedlają rejony basenu Morza Śródziemnego oraz wybrzeża zachodniej i północnej Europy - m.in. B. maritima Arcang. Najczęściej stosowaną metodą ochrony zasobów genowych buraka jest długoterminowe przechowywanie prób nasion w niskiej temperaturze pozwalającej na zachowanie ich wysokiej żywotności. Obecnie w banku genów Krajowego Centrum Roślinnych Zasobów Genowych w Radzikowie zgromadzonych jest ponad 500 bardzo zróżnicowanych obiektów tego gatunku.

Ponadto, niezwykle istotną kwestią dla hodowli jest selekcja i tworzenie materiałów odpornych na stresy biotyczne i abiotyczne wywołujące duże straty plonu takie jak: chwościk buraka (Cercospora beticola Sacc.) czy niekorzystne warunki atmosferyczne (susza).
Zmieniające się sukcesywnie środowisko wymusza na hodowcach prowadzenie prac w kierunku tworzenia nowych form buraka cukrowego odpornych na grzyb $C$. beticola oraz o podwyższonej tolerancji na stres suszy. Podstawową metodą hodowli jest intensywna selekcja pod kątem badanej cechy prowadzona $\mathrm{w}$ warunkach prowokacyjnych. Prace badawcze prowadzone są na zróżnicowanym genetycznie materiale hodowlanym buraka cukrowego. Do badań w kierunku odporności na porażenie przez grzyb $C$. beticola wykorzystano zmodyfikowaną metodę laboratoryjną opracowaną przez Stähle-Csech i Gisi (1991), która pozwala na szybką, niezależną od warunków pogodowych ocenę populacji w teście in vitro. Przebadano 70 linii buraka cukrowego (11 000 roślin) w typie 2xZN generacji S1 i S2. W toku prowadzonych prac wyprodukowano przy udziale wyselekcjonowanych genotypów 20 mieszańców, z których jedenaście (generacji S2) przekazało wyselekcjonowaną cechę potomstwu, co zostało potwierdzone statycznie. Prace badawcze w kierunku tolerancji na suszę prowadzone są w warunkach kontrolowanych $\mathrm{w}$ pojemnikach wypełnionych glebą oraz w warunkach polowych, w których wykorzystywane są te same linie ojcowskie. W okresie wegetacji prowadzona jest ocena cech morfologicznych roślin oraz przyrostów liści i korzeni w zależności od wilgotności gleby w dwóch terminach. Przyjęto dwa poziomy wilgotności gleby. Łącznie przebadano 23 linie ojcowskie i na podstawie wstępnych badań do dalszych prac wytypowano 2 genotypy buraka cukrowego.

\section{Literatura}

Gośka M. 1997. Haploidy i podwojone haploidy buraka cukrowego (Beta vulgaris L.) oraz możliwości ich wykorzystania w hodowli. Monografie i Rozprawy Naukowe IHAR Nr 2.

Stähle-Csech U., Gisi U. 1991. Determination of the sensitivity to DMI fungicides of Cercospora beticola on sugar beet. EPPO Bulletin 21: 321 .

Sponsorzy konferencji Dzień Młodego Naukowca 2018

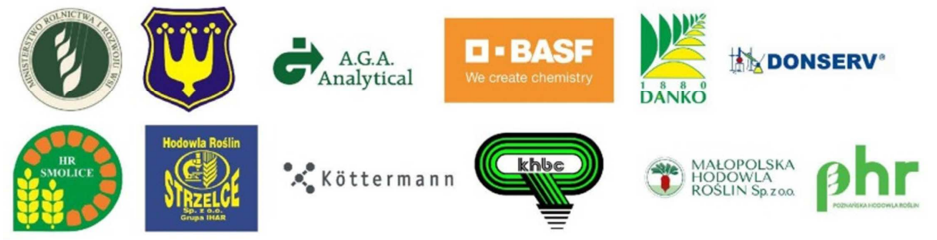

